DOI: https://doi.org/10.47405/mjssh.v6i11.1151

\begin{tabular}{|c|c|}
\hline 4 & Malaysian Journal of Social Sciences and Humanities (MJSSH) \\
\hline $\begin{array}{l}\text { Malaysian Juoural of } \\
\text { Social ccciecces and }\end{array}$ & Volume 6, Issue 11, November 2021 \\
\hline (MJ-sSH) & e-ISSN : 2504-8562 \\
\hline & $\begin{array}{l}\text { Journal home page: } \\
\text { www.msocialsciences.com }\end{array}$ \\
\hline
\end{tabular}

\title{
Influence of Branding Loyalty on Consumer Sportswear: A Case Study on Adidas
}

\author{
Noor Syafika Binti Mohamed Shoffian', Nur Syafinaz Binti Mohamed Salim¹, \\ Nurul Izzati Binti Razali1, Putera Zariq Iskandar Bin Muhamadi Saifulizan1, \\ Siti Aishah Binti Abu Bakar', Siti Nur Afiera Binti Rossedi', Wahyu Irmayani Binti Suwirman', \\ Vimala Davy G. Ramiah², Sio Ching Hee ${ }^{3}$, Isai Amutan Krishnan ${ }^{4}$ \\ 1 University of Malaya Centre for Continuing Education (UMCCeD), Malaysia \\ 2Institute Aminuddin Baki, Sarawak Branch, Kuching, Sarawak, Malaysia \\ ${ }^{3}$ ELM Business School, HELP University, \\ Jalan Sri Semantan 1, Off Jalan Semantan, Bukit Damansara, 50490 Kuala Lumpur, Malaysia \\ ${ }^{4}$ School of Liberal Arts, Science and Technology, PERDANA University, Suite 5.3 5th Floor Wisma Chase Perdana Jalan \\ Semantan Damansara Heights, Wilayah Perseketuan, Malaysia \\ Correspondence: Isai Amutan Krishnan (amuthanisai@gmail.com)
}

\begin{abstract}
Brand loyalty creates long term relationship between customer and brand. As a sportswear brand, to adopt a general customer loyalty to a brand, quality of the product and price are the crucial factors. The purpose of this research is to investigate how the respondents are influenced by factors of brand loyalty towards sportswear products. Previous research adopted seven factors to test in the Malaysian environment. The seven factors of brand loyalty are brand name, product quality, price, style, promotion, service quality and store environment. Brand name has shown strong correlation with brand loyalty. In order to increase customer satisfaction and attach them to be brand loyalists, marketers are encouraged to develop aggressive marketing programs. Questionnaires were distributed to 148 respondents. The research results have shown that there is positive and significant relationship between factors of brand loyalty (brand name, product quality, price, style, promotion, service quality and store environment) with certain sportswear brands. Others study on more focused factors that are appropriate to the Malaysian environment is recommended in order to obtain accurate information.
\end{abstract}

Keywords: brand loyalty, factors, sportswear, Malaysia

\section{Introduction}

In Malaysia, sportswear brands such as Nike, Adidas, and Reebok, Puma, Fila and Umbro are popular among sportswear consumers especially teenagers as they suit with a various outfits that are comfortable. The companies try to enhance brand loyalty among their customers as it gives potential to gain higher profit. According to Nikhashemi, Haj Paim, and Ali Khatibi (2015) brand loyalty is a repurchase decision that can be passed by words of mouth which refers to the perception of customers on the quality of the products.Adidas is one of the strongest sports brands in the world. Unfortunately, according to Jalila Abd Mukhti (2011), there are several issues that make people not loyal to Adidas. Due to its strong brand name, the prices of Adidas sportswear are relatively expensive, and this is because of innovative technology and production. In addition, Adidas is a brand name that has a high cost and low profit. They are running a risk of over dependency on outsourcing especially in Asian 
markets as they want to take care of the quality of their products. Adidas is also weak in marketing research. Adidas should develop their sportswear products of with the latest designs. Lastly, the quality of the product is the main priority to the customers. Therefore, the objective of the study was to identify and critically evaluate factors that influence brand loyalty of a sportswear's company particularly the brand loyalty of Adidas's customer and evaluate factors that influence customers of Adidas to remain loyal.

\section{Literature Review}

In Malaysia, sportswear brands like Nike, Adidas and Reebok are popular among sportswear customers. Young people take Sportswear as a general and popular category of clothes because it is identified by them with greater flexibility, comfort, and more relaxed lifestyle. Manufacturers such as Adidas and Nike started expanding their business especially in Asia to achieve higher volume of sales for their products. Many companies try to increase brand loyalty among their customers, particularly in the sportswear industry. Brand loyalty is defined as a customer's careful or careless decision which is represented by the willingness or attitude of repurchasing continuously a definite brand. The final goal of marketing is popularly known as brand loyalty (Will Kenton, 2018). Brand loyalty suggests a customer's pledge of repurchasing the product of the same brand repeatedly or purchasing a service with positive attitudes. This suggests that the repeated purchase decision is greatly dependent on the quality of the performance of the product or service Kabu and Soniya (2017).

Based on a previous study, a unique model was used by Hamer and Muniz (2001) for studying oppositional behaviour of brand loyalty in the social environment. The researchers used newsgroups of Usenet, the function of which was similar to electronic bulletin boards for tracking what people saying regarding their preferred brands. They also obtained information regarding the competing brands and the oppositional loyalty is revealed in two ways. In the first case, customers will outline their preferred product categories by what they consumed and did not consume. In the second case, customers will reveal their disagreement towards the competing brands as well as start playful competitions with the consumers of the competing brands. In many cases the second one is followed by the first one. Therefore, the study reflects the fact that some of the customers develop a part of the meaning of the brand as well as their disapproval from the opposition towards competing brands.

According to Nawaz and Usman (2011) the central role of marketing strategies is the development and maintenances of customer brand loyalty, especially in markets with strong competition, great unpredictability, and decrease in product differentiation.

According to Brown et al. (2012) there are a set of seven essential as well as mutually satisfactory conditions that can be defined as brand loyalty. They explained the combination of six factors i.e. nonrandom, behavioural reaction, expression over time, and decision-making process, in comparison to some other brands and their functions are psychological (evaluation, decision making etc) procedures. They added that statements of inclination or else aim of buying i.e. verbal reports of loyalty are not enough to explain loyalty. In order to consider brand loyalty, verbal reports must be pooled with the loyal behaviour of purchasing among customers. This article provides a broad meaning of brand loyalty applicable in the work place and hence, the article is very much crucial to this research.

On the other hand, Rahil Khoei (2014), examine factors leading towards brand loyalty and brand personality behaviour on sportswear. He mentions the key factor of brand loyalty include brand name, product quality, price, style, store environment, promotion and service quality. The consumers were classified in terms of their loyalty and their perception and interest for every of these seven brands and to distinguish consumers by different factors and dimensions of brand loyalty.

Another study was conducted by Renaldo Wijaya Lim and Atik Aprianingsih (2015) with the objective of learning what makes a customer loyal toward a sportswear brand. They revealed that if sportswear could learn from the factors influencing brand loyalty then any sportswear brand could be built in big cities. 
According to Pragashini et al. (2015), for marketers to compete in the growing sporting goods market, they need to understand their customers' behaviour patterns. Therefore, it is necessary to determine the significance why a select group of factors influence customer choices of purchasing of sporting goods. Marketers need to focus more on this variable in order to take advantage of the numerous opportunities in the growing sporting goods market.

Based on the study by Mohamed Soltanhoseini and Nasim Azimi (2015) that attempted to evaluate and prioritize the factors affecting the loyalty of athletes Sports Brands. They revealed that among other components are the style of the product, social class, lifestyle, quality of services, and the volume of advertising in the priority groups. Furthermore, it is said brand loyalty is an important concept that has been designed for understanding costumer behaviour.

The study by Khor, Lim, and Siti Norshilla Mohd Aris (2016) relates the perspective of brand loyalty as perceived by youths using two validated dimensions, namely internal brand loyalty and external brand loyalty . Generally, it could facilitate marketers to plan and coordinate their marketing strategies in sport industries.

Based on the research by Xi Axin Dai and Kuan (2017), brand managers should not only focus on increasing the quality of the product and establishing their brand name but should also pay attention to their store environment, promotion, the quality of service of their employees and the style of their products. In addition, it may provide some references for brand managers in making business plans and changing their existing strategies.

Lastly, in a study of Zhang Yu, Li Pensing, Cao Houwen, Cao Ling and Li Na (2017), has revealed there is need to explore the formation mechanism of the customer loyalty the brand of sport goods and improve the competitiveness of sport goods enterprises. Therefore, the customer loyalty can be improved by enhancing perceived quality, customer value, and customer satisfaction. The literature review provides an overview on brand loyalty that has provided the background for this article and has mentioned that there are seven factors which are brand name, product quality, price, style, store environment, promotion and service quality.

\section{Definitions}

There are many operational definitions of brand loyalty. In general, brand loyalty can be defined as the strength of preference for a brand compared to other similar available options. Brand loyalty is a function of both behaviour and attitudes. It is a consumer's preference to buy a particular brand in a product category. It occurs because consumers perceive that the brand offers the right product features, image, or level of quality at the right price. This perception becomes the foundation for new buying habits. Consumers will initially use the product on a a trial basis and, when satisfied with the purchase, will continue to purchase the same brand because the product is safe and familiar.

\section{Methodology}

The questionnaire was distributed to the customers of Adidas. The questionnaire was taken from a previous study by Mollika Mollika. The questionnaire will be distributed to the 148 respondents who range from 20 years old and above. The instrument is a questionnaires which consist of two sections. Section A is demographic information. Section B are the factors that lead to the brand loyalty of Adidas. 


\section{Results}

This section will be analysing the data that was obtained from the questionnaire that had been distributed to the customers of Adidas. The data that had been analysed will be also discussed in this section to show the comparison and similarity of this research and the previous research.

A survey based on case study was conducted to find out the influence of brand loyalty of Adidas as consumer sportswear. It was divided into 8 variables namely product quality, product style, product brand name, store environment of product, services quality provided, product promotion given, and product price.

The demographic section was divided into three namely gender, races, and age average. According to gender, Adidas sportswear is male dominated and used by 80 respondents which is $54 \%$, This is followed by 68 female respondents which is $46 \%$. Next, according to races the Adidas sportswear is most popular among Malays with $61 \%$. This is followed by Chinese with $26 \%$, Indians with $10 \%$ and other races 3\%. Lastly according to age average, the Adidas sportswear is the highest among the 21-30 years old with $45 \%$. This is following by those in the $1-20$ years age group with $43 \%$ and $12 \%$ above 31 years old.

Figure 1: Demographic analysis

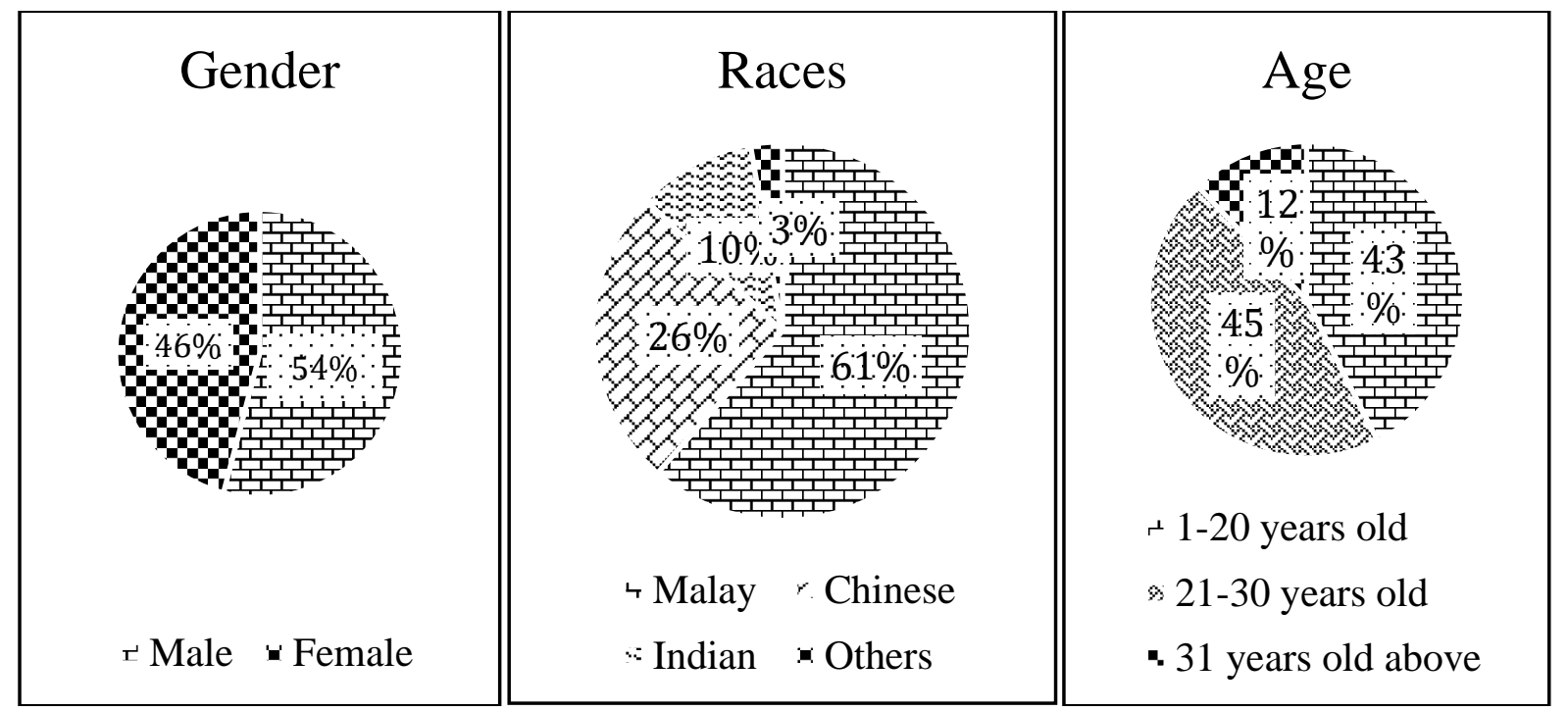

Figure 2: Product quality analysis

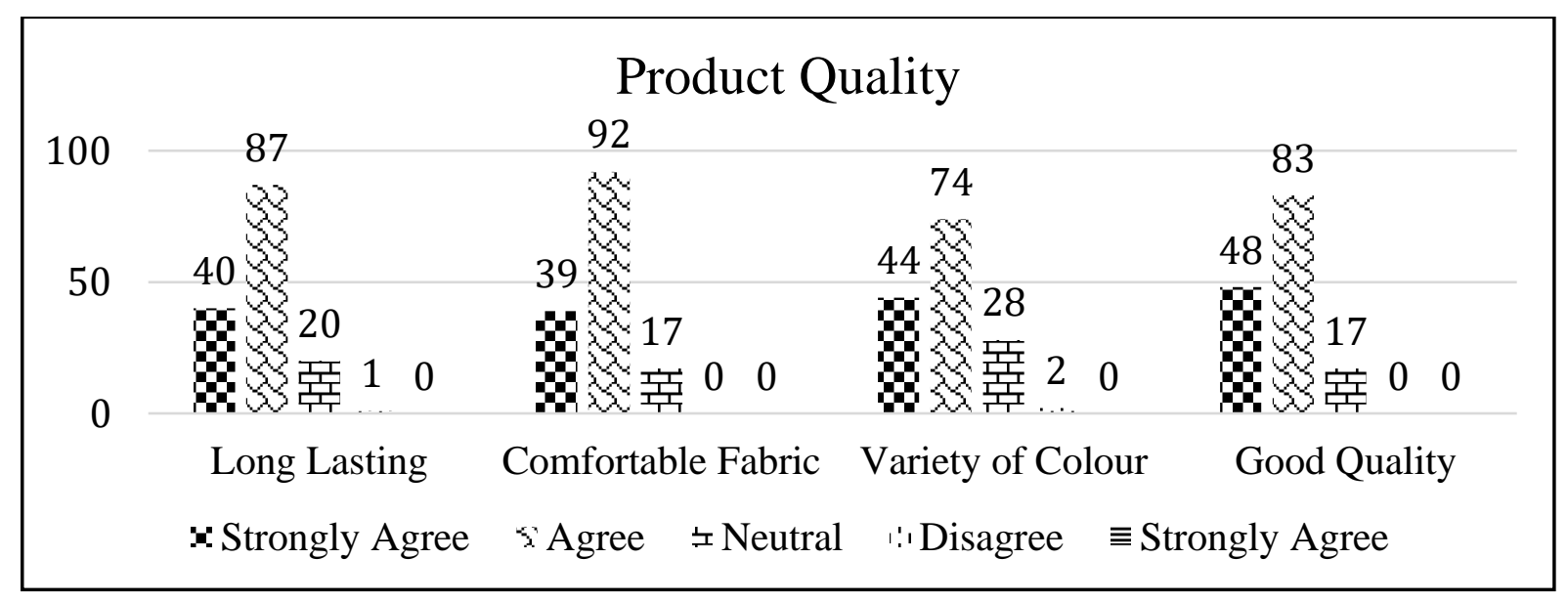


The first variable in the survey is related to the quality of the product of Adidas sportswear. Most of the respondents that is 87 out of 148 agreed with the quality of the product that it is long lasting. Another 92 respondents agreed that the fabric used was comfortable. Besides that, 148 respondents that forms a majority agreed that Adidas sportswear products are in a variety of colours, are good and of high-quality compared to other products.

Next, the style of Adidas sportswear products also got the same result like the quality of Adidas sportswear. A majority of the respondents that is 148 of them agreed with the style of Adidas sportswear. The different styles provided for teenagers and adults are very convenient used. Another 148 of the respondents agreed that Adidas sportswear are very exclusive in style and fashionable when people wear them. The style of Adidas is very suitable in fashion for teenagers and adults.

Figure 3: Style analysis

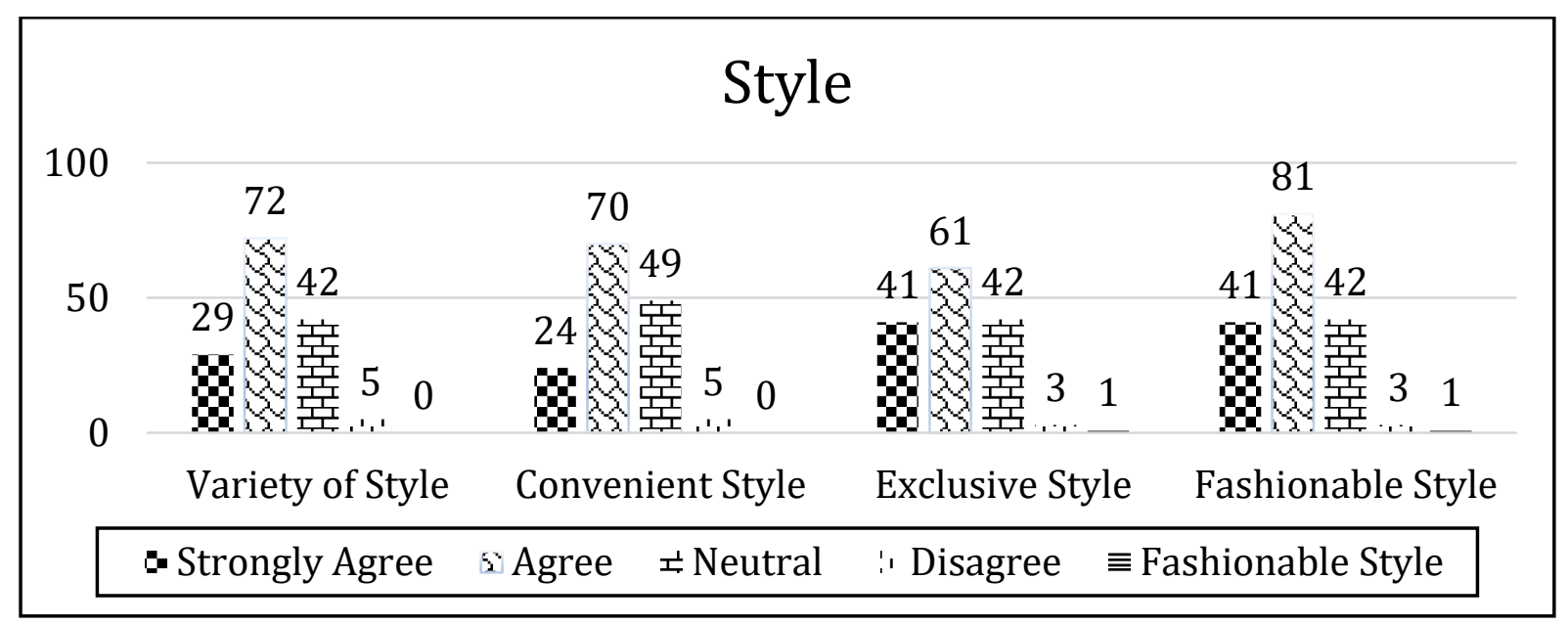

Next, another variable that was been researched by team was about the brand name of the Adidas sportswear product. There were 86 respondents who strongly agreed that Adidas sportswear was a product with a good brand reputation since 1949 based on respondents' satisfaction of the quality and the style of the product. There were only 42 respondents who strongly agreed that the Adidas brand name encouraged people to buy their products. Majority of respondents agreed the Adidas brand name encouraged people to buy their products as there were many other brands of sportswear such as Nike, Puma and Original Classic. Besides that, a majority of the respondents were Neutral for the price and personality representation that encouraged people to buy this product.

Figure 4: Brand name analysis

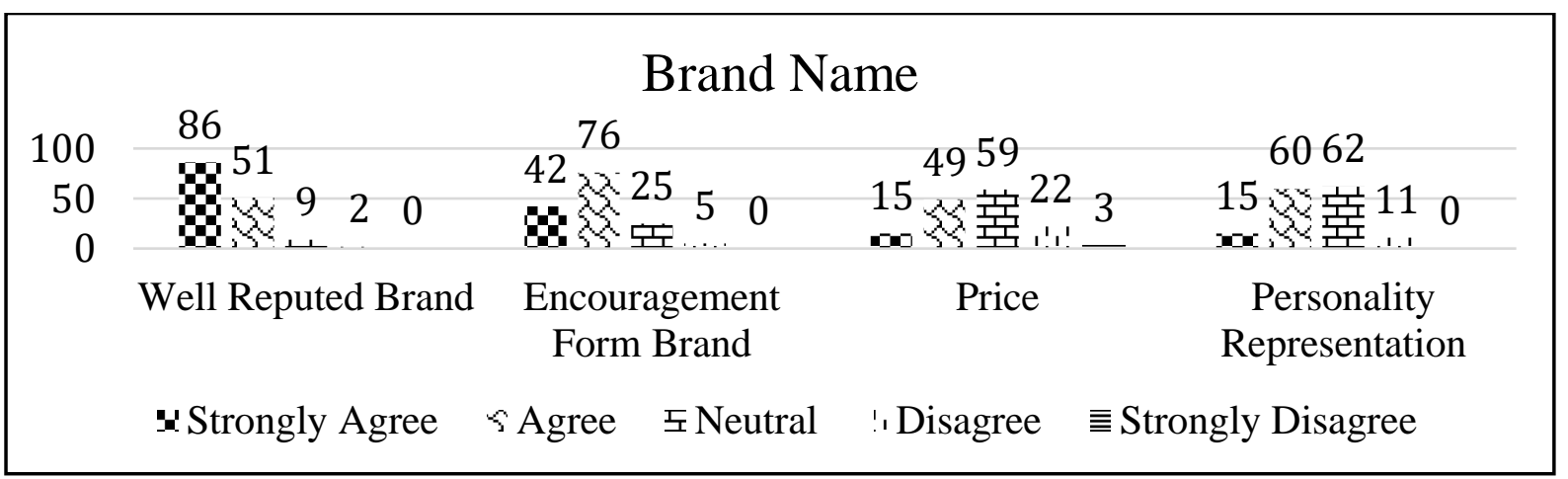

Furthermore, store environment of Adidas is one of the variables that was investigated by team. A total of 148 respondents agreed with the store environment and convenience store of Adidas that actually encouraged people to come and buy the products provided by Adidas. Besides that, the 148 respondents agreed that Adidas had nice-looking stores and also sufficient outlets with complete sportswear products. 
Figure 5: Store environment analysis

\begin{tabular}{|c|c|c|c|c|}
\hline \multicolumn{5}{|c|}{ Store Environment } \\
\hline \multirow{5}{*}{$\begin{array}{r}100 \\
50 \\
0\end{array}$} & 82 & 86 & 78 & 79 \\
\hline & $20 \ll 40$ & $28 \stackrel{x}{x}$ & 3830 & $27 \lll 38$ \\
\hline & 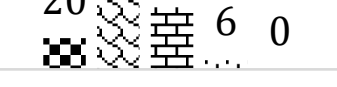 & Bx婜 30 & $\mathbf{B}$ 3 20 & $8 \times$ 監 31 \\
\hline & Convenience Place & Sufficient Outlet & Nice-looking Store & Good Environment \\
\hline & $x$ Strongly Agree & $>$ Agree $\mp$ Neutral & $\because$ Disagree $\equiv \mathrm{Str}$ & ongly Disagree \\
\hline
\end{tabular}

Moreover, the service quality provided by Adidas was also one of the questions in the survey . It was found 148 respondents agreed that the services provided by Adidas salesperson were friendly and enthusiastic. So, it shows that the respondents are happy with the salesperson's attitude towards them and they guide them to repurchase Adidas products. The salesperson at Adidas store are not only friendly and enthusiastic, but they are very attractive person and good person. This is also makes the respondents very comfortable when shopping at Adidas store.

Figure 6: Service quality analysis

\begin{tabular}{|c|c|c|c|c|}
\hline \multicolumn{5}{|c|}{ Service Quality } \\
\hline \multirow[t]{3}{*}{$\begin{array}{r}100 \\
50 \\
0\end{array}$} & 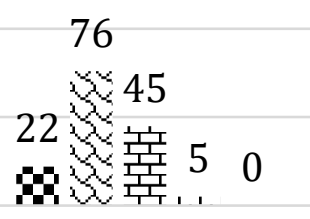 & 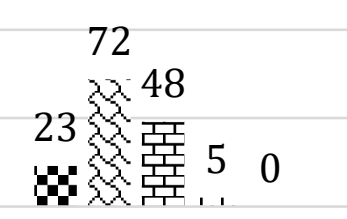 & 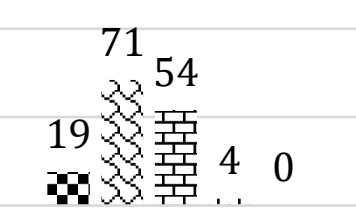 & $\begin{array}{c}76 \\
26 \ll 41 \\
8 \ll \text { 㰓 } 50\end{array}$ \\
\hline & Good Person & $\begin{array}{l}\text { Enthusiastic } \\
\text { Salesperson }\end{array}$ & Friendly Salesperson & $\begin{array}{l}\text { Attractive } \\
\text { Appearance }\end{array}$ \\
\hline & Strongly Agree & Agree $\quad$ ᄃ Neutral & $1 \quad$ i Disagree $\equiv \mathrm{Str}$ & ngly Agree2 \\
\hline
\end{tabular}

In additional, another variable examined by the team was the content of the promotion. There were 148 respondents that was the largest agreed that Adidas provided attractive advertisements for the purpose to encourage people to buying their products. The attractive advertisement provided by Adidas also increased the purchasing power of consumer.

Figure 7: Promotion analysis

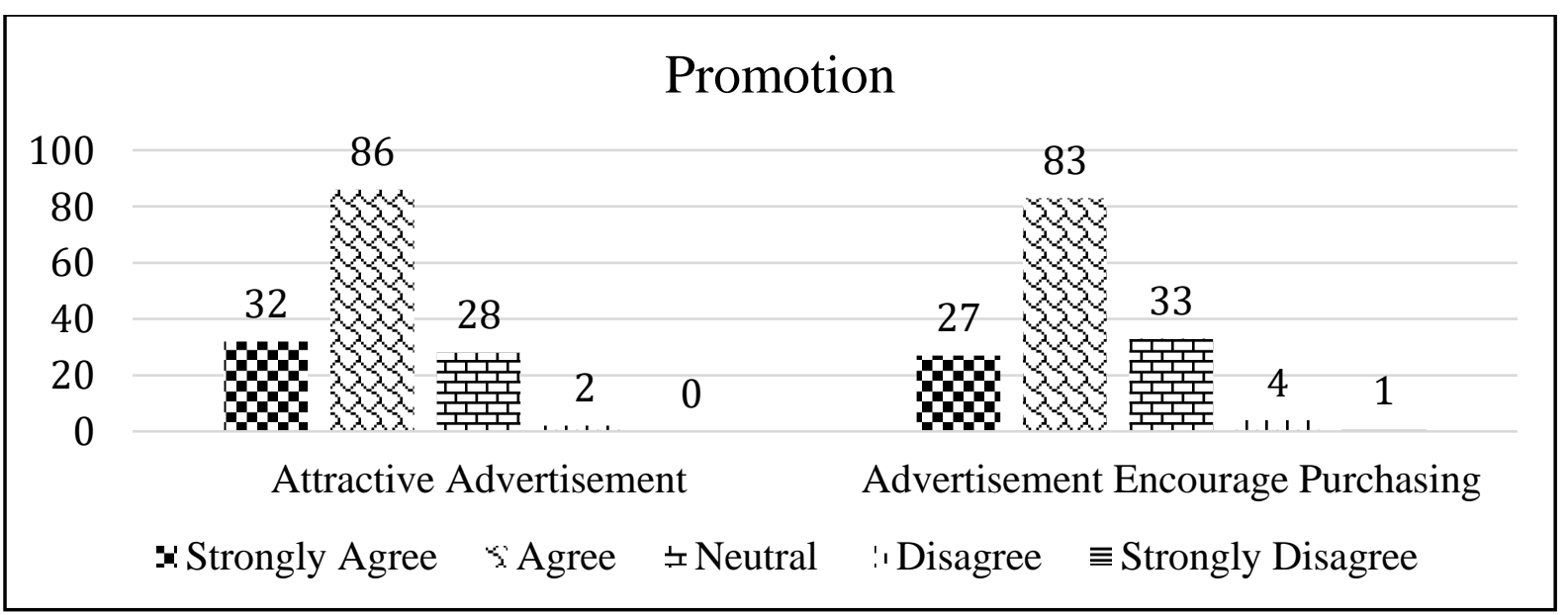


Lastly the price of Adidas sportswear was also another variable on the survey among the 148 respondents. There were 67 from 148 respondents who agreed that the price of the Adidas products was affordable for the quality and was suitable with price that offered. However, only 57 respondents were "neutral" for the increasing of the price.

Figure 8: Price analysis

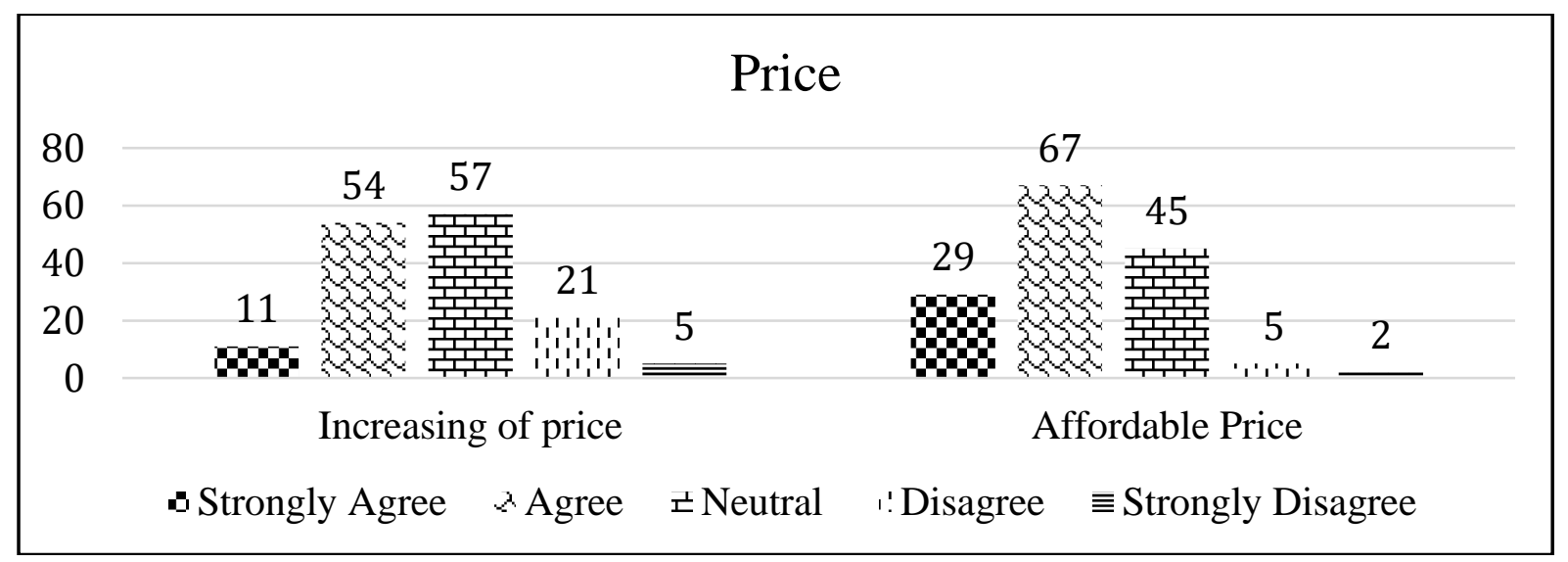

\section{Discussion}

Based on the findings that had been discussed in this study, it obviously shows that product quality is the most important factor that will lead towards brand loyalty. Consequently, the company should focus more on these factors. From this research, it also can be observed that the main factor that influence brand loyalty for Malaysia is the same for quality as mentioned by Renaldo Wijaya Lim and Atik Aprianingsih (2015). However, based on the research that was made by Mohamed Soltanhoseini and Nasim Azimi (2015), components of price, the volume of advertising, lifestyle and store environment were stronger predictors for sports brands in Iran which was totally different from the result of this study. Based on the research that was made by Xi Axin Dai and Kuan (2017), the most significant factors that led to the brand loyalty in Hong Kong University was product quality and brand images. It is reasonable and acceptable because the respondents of the research are from students who obviously prioritized the brand images which have high quality. The result is also influences by the artificial products that are produces by China.

Even though the main important factors that lead to brand loyalty of Adidas in Malaysia is product quality, but the company should not ignore other factors such as style, and store environment. It is important to maintain the customer's loyalty towards the product, as the company should maintain other factors that make an improvement to the main factors that can lead to the brand loyalty of the product. Based on this research surprisingly there is an unexpected result which is the price that moderated on the factor of brand loyalty of the product. It maybe because people prioritized the product quality and ignored the price that was offered. They are willing to pay more if the quality of the product is suitable for the price.

In the discussion part, we will discuss briefly the implication of this study to compare this study and the past studies. The implications will also be discussed as part of the study. One of the implications of this study is to help the brand managers by providing the information collected from the customers of Adidas itself. The implications of the study made by us is the same as the past studies, The study by Xi Axin Dai and Kuan (2017), is to provide the information about customer's brand loyalty based on the consumer's viewpoint. The information can help the managers to put themselves in the consumer's position, and the strategies they make will also be accepted easily by customers. So, it can be seen that the accuracy of the implications of this study has already been proven by the past study.

Based on this research, there was only factor that supported brand loyalty that is the product quality, but it did not mean that the other factors are unnecessary. This is because there is a limitation that 
occurred when conducting this survey that makes the result become slightly different from the actual situation. It means that the manager should not ignore the other factor that can influence brand loyalty as all the factors will distribute to the loyalty of the consumers towards the product. Even though Adidas is a well- known brand, they should always maintain and improve their quality, style, and others always. It is because, it is hard to get loyal customers, but easy to lose them.

\section{Implication}

The purpose of this research is to identify the impact of brand loyalty on Adidas customers. To find out the factors that influence loyalty of customers of Adidas, a survey was conducted on 148 customers in three different stores of Adidas in Midvalley, The Garden and, Pavillion. The survey comprises of eight sections and responses are collected on a 5-point Likert scale. Graph analyses have been used to analyse the results of the research. The paper finds a high degree of positive correlation among the independent and dependent variables, and thus customer preference is dependent on various brand loyalty tools that include the name of the brand, quality of product, price, promotion, service quality and, store environment, These factors influences the customers significantly in order to increase customer satisfaction and drive them to be brand loyal. This study is more focused on factors that influence the branding loyalty on customer's sportswear. The research results show that there is a positive and significant relationship between factors of brand loyalty and sportswear brand loyalty.

The findings of the study have several implications. First, helps the brand managers in making business plans and changing their existing strategies. Building brand loyalty will contribute positively to the firm's brand equity. It has several important strategic benefits to the firms, such as gaining high market share and new customers, supporting brand extensions, reducing marketing costs, and strengthening the brand against competitive threats.

Second, the findings provide further insights that it is very important for companies to maintain their brand performance so that they meet customer expectations. Major branded companies should continue to build trust in their brand, develop additional functional features such as enhanced features in their cell phones and conduct market research as promotion is one of the major factors of customer buying the product All these can indirectly find out more about what customers expect from a brand. Thirdly, retaining customers is very important for the future of many companies, especially in the sportswear industry where product differences are minimal in terms of the brand name. Marketers can include findings from this study to formulate responsive marketing strategies.

Finally, the findings from this research are to get a customer's loyalty based on the results from the customer's viewpoint. It can be seen that the main factor is product quality. Additionally, the present study may have potential implications for future research since it may yield different results in different product categories example how each of the major determinants affects the brand loyalty of consumers.

\section{Conclusion}

The research was conducted with the objective of finding the influence of brand loyalty on consumer sportswear particularly on customers of Adidas brand. Brand loyalty is vital for a firm because it ensures that customers will keep in mind its product and ensures that they will not shift to other brand product. From the research, we found that gaining and maintaining customer's loyalty is not easy.

There are many forces that lead customers away like such as competition, customers' interest for variation and so on. According to the implications of the study, it was found that there were seven important factors of brand loyalty appropriate for society namely the brand, quality of product, price, promotion, service quality, style and, store environment of Adidas. To convert a general customer to become a loyal customer to a brand, quality of the product is a crucial factor. It is noticed that quality of the product is also a significant factor in Malaysia. Thus, this study also shows that Malaysians 
prefer the seven dimensions of brand loyalty as significant factors that influence customers decision compared to other related factors concerned with brand loyalty. All the factors showed a significant positive relationship with brand loyalty. Unavoidably, Adidas is a successful entity in managing brand loyalty by offering large potential in the sportswear market where there is an increase in sporting activities and high demand for sportswear's. There are many ideas on which further studies can be conducted to gain a better understanding of branding loyalty on consumer sportswear in Malaysia. The selection of the sample can be improved as this study did a convenient sampling of consumers around three shopping mall (Midvalley, The Garden and Pavillion). This study could be further expanded to other places like gyms, fields or any other place that consist of sports person. Target sampling of certain segment could also be done to get a better survey of the certain targeted market of interest. It is also important to investigate how Malaysian consumers mindsets in Adidas brand compare with other brands.

Further studies are recommended to compare other sportswear brands such as Nike, Reebok and Puma that are also well-known brands among sportswear consumers. This is because Malaysian consumers have knowledge about sportswear brand attributes, intangible benefits of the brand, brand class, customer benefits in using the sportswear brand and relative prices of the brands. In addition, further studies are recommended to get more information regarding how the sportswear were being used by the respondents, it will be interesting to know whether the sportswear is for serious outdoor sports or indoor fitness usage or only as casual wear would be useful for further deliberations and conclusion of other studies. Lastly, it would be interesting to include the career of the respondent in the questionnaire. The customers feel the newfound sportswear apparel of greater appeal not just in sporting activities but also as clothing suitable for use at home, in school, at work or at leisure. This is greatly reflected in the prominent trend in the sportswear industry which has seen a convergence between casual design and athletic design in sportswear.

\section{References}

Abd. Mukhti, J. (2011) Adidas latest 1. Retrieved from https://www.scribd.com/doc/55102483/Adidas-Latest-1. (n.d.).

Albert M. Muniz, Jr. and Lawrence O. Hamer (2001), "Us Versus Them: Oppositional Brand Loyalty and the Cola Wars", in NA- Advances in Consumer Research Volume 28, eds. Mary C. Gilly and Joan Meyers-Levy, Valdosta, GA: Association for Consumer Research, Pages: 355-361.

Brown, Charnetta; Randolph, Adriane B.; and Burkhalter, Janée N. (2012) "The Story of Taste: Using EEGs and Self-Reports to Understand Consumer Choice," The Kennesaw Journal of Undergraduate Research: Volume 2: Iss.1, Article 5

Dai, X., \& Chen, K.C. (2017). Examining Antecedents of Brand Loyalty on Sportswear: An Empirical Investigation of University Students in Hong Kong. International Journal of Social Science Studies, Vol. 5, No. 7, Pages: 2324- 8033.

Fard, M.K., Ismaeelzadeh, R., \& Ramshini, R. (2016). Effect of sports brands on loyalty in sport customers. Glob. J. Sci. Res., journal, 4(5) Pages: 74- 79.

Kenton, W. (2018) What Is Brand Loyalty? Retrieved from https://www.investopedia.com/terms/b/brand-loyalty.asp

Khadka, K., \& Maharjan, S. (2017) Customer Satisfaction and Customer Loyalty. Retrieved from http://www.easybib.com/reference/guide/apa/website

Khor, P. H., \& Mohd Aris, S.N. (2016). Dimension of sports brand loyalty among youths in Perlis. International Academic Research Journal of Social Science, 2(1) Pages: 49-54.

Khoei, R. (2014). Brand loyalty in sportswear in Iran. International journal of Management, Accounting and Economics, Pages:2383-2126

Lim, R.W., \& Aprianingsih, A. (2015). Factors influencing brand loyalty towards sportswear in Bandung. Journal of Business and Management, Vol.4, No.8, Pages: 932-943.

Mollika. (2013) Impact of Brand Loyalty on Sportswear Customers:

Case Study of Adidas. Retrieved from

https://www.academia.edu/7639671/Impact of Brand Loyalty on Adidas 
Malhan, S., Khanna, D.P., \& Anjum, D.B. (2018). Factor affecting brand loyalty of branded sport shoes in Athletic footwear industry, Pages: 2277- 2723.

Nikhashemi, S.R., Paim, H., \& Khatibi, A. (2015). The Role of Brand Loyalty in Generating Positive Word of Mouth among Malaysian Hypermarket Customers. World Academy of Science, Engineering and Technology International Journal of Economics and Management Engineering.

Pilai, P., Soni, S., \& Naude, M. (2015). Selected factors as determinants in the purchase choice of sporting goods. Problems and Perspectives in Management, 13(3-1), 216-223.

Soltanhoseini, M., \& Azimi, N. (2015). Evaluating the effective factors in loyalty of athletes to sports brands in the archery league teams. International journal of academic research in business and social sciences, 2222-6990.

Yu, Z., Pengsong, L., Houwen, C., Ling, C., \& Na, L. (2017). An empirical study on the customer loyalty to sports goods brand. Science journal of education, 5(3), 111-114.

\section{Authors' Detail}

1. Noor Syafika Binti Mohamed Shoffian, Nur Syafinaz Binti Mohamed Salim, Nurul Izzati Binti Razali, Putera Zariq Iskandar Bin Muhamadi Saifulizan, Siti Aishah Binti Abu Bakar, Siti Nur Afiera Binti Rossedi and Wahyu Irmayani Binti Suwirman. These authors were Diploma final year students from University of Malaya Centre for Continuing Education (UMCCeD). This was a group work for Business Research Methodology UDE 2012 which was supervised by Mr. Isai Amutan Krishnan and Ms. Vimala Davy G. Ramiah and Ms. Sio Ching Hee who contributed significantly for completing this final year project.

Address: Wisma R\&D University Malaya, Jalan Pantai Baharu, 59100 Kuala Lumpur, Federal Territory of Kuala Lumpur

2. Vimala Davy G. Ramiah is currently the head of department of the Department of Staff Development at Institute Aminuddin Baki, Sarawak Branch in Kuching, Sarawak. She was prior to this the Head of Unit at the Schools and Sports Divisions of the Ministry of Education in Putrajaya. She has more 32 years of working experience in the field of education with the Ministry of Education, Malaysia. Her research interests are in communication, applied linguistics and Teaching English as a Second Language.

Email:vimala@iab.edu.my, HP: 0192194642

Address: Institut Aminuddin Baki Sarawak Branch, Jalan Sultan Tengah, 93050 Kuching, Sarawak.

3. Sio Ching Hee: Lecturer/Trainer, ELM Business School, HELP University, Jalan Sri Semantan 1, Off Jalan Semantan, Bukit Damansara, 50490 Kuala Lumpur, Malaysia.

4. Isai Amutan Krishnan: Senior Lecturer, School of Liberal Arts, Science and Technology, PERDANA University,Suite 5.3 5th Floor Wisma Chase Perdana Jalan Semantan Damansara Heights, Wilayah Perseketuan, Malaysia. 